\title{
The Lexicalization Patterns of Manner Motion Events in Vietnamese
}

\author{
Asso.Pro.Dr. Luu Quy Khuong ${ }^{1} \&$ Ly Ngoc Toan ${ }^{2}$, MA \\ ${ }^{1}$ University of Foreign Language Studies- The University of Da Nang, Vietnam \\ ${ }^{2}$ Banking University, Vietnam \\ Correspondence: Ly Ngoc Toan, MA, Banking University, Vietnam. E-mail: toanln@ buh.edu.vn \\ Received: October 18, 2018 \\ Accepted: November 20, 2018 \\ Online Published: November 21, 2018 \\ doi:10.5430/elr.v7n4p1 \\ URL: https://doi.org/10.5430/elr.v7n4p1
}

\begin{abstract}
The purpose of this paper is to illustrate how Vietnamese students lexicalize or express in words the idea of motion. This study was conducted on the traditional foundation of Talmy's (1985) lexicalization patterns. This theory involved in the way of people's experience is rendered into languages via the semantic content of lexical items to express experiential categories. The data were derived from the analysis of the writings of fifty $12^{\text {th }}$ - graders and fifty $6^{\text {th }}$ - graders at Phu Rieng secondary school, Binh Phuoc province, Vietnam about the picture story "Frog where you" are by Mayer (2003). The results of the research provided insights into how Vietnamese speakers express the experience of motion in their language. These results suggest that there are considerable differences between Vietnamese and some other languages in the accounts of motion events.
\end{abstract}

Keywords: lexical expression, spatial component, conflation, manner motion, and event

\section{Introduction}

So far there have been a wide range of studies which are concerned with motion in Vietnamese (Nguyen Lai, 2001; Ly Ngoc Toan, 2013; Nguyen Thanh Minh, 2015). However, these works mainly focus on the classification of Vietnamese motion verbs based on Talmy's (1985) two- way typology regarding motion, and they have hardly paid attention to the analysis of motion as expressions. Accordingly, this research will bridge this gap.

This research focuses on delving into Talmy's (1985) theory of lexicalization patterns; He takes in-depth insights into the ways of how semantic elements are mapped on surface structures (linguistic forms) and to delve into the relationship between semantic elements and surface forms. It is a theory that has engendered a wide range of cross-linguistic research worldwide (Ferez 2008, Ibarretxe-Antunano 2004, Pourcel 2005, and Slobin 2004). More particularly, this theory helps to investigate how semantic elements are conflated into motion verbs.

Based on the principles of this theory, the researchers clarified the semantic and syntactic features of lexical expressions of the manner motion in Vietnamese through the analysis of the Vietnamese secondary school students' writing. The contribution of this study is to provide both theoretical and practical aspects. In terms of the theoretical contribution, this research built the patterns denoting the manner motion in Vietnamese. In addition, this research also has a considerable contribution to the Vietnamese language teaching to foreigners.

\section{Theoretical Background}

The section shed on the semantic and syntactic properties of lexicalization patterns denoting motion, and the properties of the manner motion as well.

\subsection{Talmy's Lexicalization Theory}

Talmy (2000b) delves into the syntactic relations in language between meaning and overt surface structures, in other words, the process of lexicalization. He notes that lexicalization is involved in where a particular meaning component is found to be in regular association with a particular morpheme (Talmy, 2000b: 24). He begins with the basic assumption in which we may isolate elements separately within the domain of meaning and within the domain of linguistic expressions.

Then, we examine which semantic elements are expressed by which linguistic elements. Talmy posits that the relationship between meaning and linguistic forms is not one-to-one; a combination of some semantic elements may be expressed by a surface form and vice versa as illustrated in Figure (1a), and Figure (1b). 


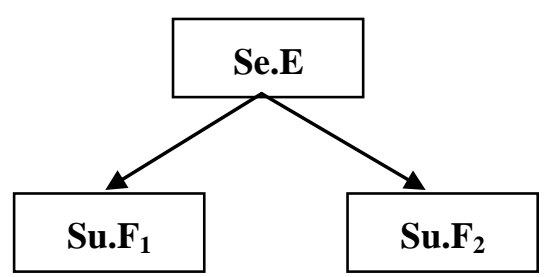

(a)

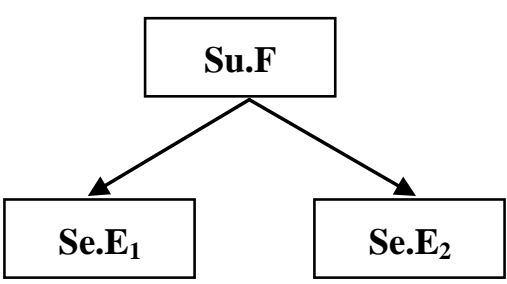

(b)

Figure 1. Relationship between Semantic elements and Surface elements

The linguistic aspect chosen for our research is motion events in what motion is one of the primary experiential domains in human life, which is, therefore, tied to be lexicalized in all languages. A Vietnamese motion verb (surface form) can encode distinct types of semantic information, which are Manner such as nảy lên (bounce), nhảy lò cò (hop), Path (e.g., vào (enter)) or Cause (e.g, đá (kick)). However, the Path element can be expressed in English by both verbs and prepositions (e.g., vào (into), $r a$ (out)), that is, by two different linguistic forms. Talmy concludes that by delving into the relation between meaning and linguistic structures, a plethora of universal principles and typological patterns might come out.

\subsection{Manner Motion}

Talmy (1985: 128) defines manner motion as a subsidiary action or state that a Patient occurs concurrently with its main action or state. Following this flow, manner motion in the Vietnamese language can be elucidated by Slobin's (2006a:62) assumption providing a thorough interpretation of what can be understood by manner motion: Manner motion is a cover term of for a number of dimensions, including motor pattern (e.g. nhảy lò cò (hop), nhảy ( jump), nhảy dây (skip)), often combined with rate of motion (e.g. đi bộ (walk), chạy ( run), chạy nuớc rút (sprint)) or force dynamics (e.g. buớc (step), giẫm (tread), buớc lên (tramp) or attitude (e.g. đi nuớc kiệu (amble), đi tho thẩn (saunter), đi dạo (stroll)), and sometimes encoding instruments (e.g. đi xe truọt tuyết (sled), truột tuyết (ski), truọt ba tanh (skateboard) and so forth.

Additionally, manner motion in the Vietnamese language could be classified according to two other assumptions by Özçalışkan (2004: 81) and Narashimban (2003: 135) as follows:

\section{a. Özçalışkan's classification}

Rapid motion (e.g. lao (dart), thoc (plunge))

Leisurely motion (e.g. trôi dạt (drift) , chìm (sink)

Obstructed motion (e.g. vấp (stumble), lọt qua (leak))

Smooth motion (e.g. truơt (slide), luót (ride))

Manner of running (e.g. chạy bộ (jog), phi (gallop))

Furtive motion (e.g. bò /truò̀n (creep)),

Manner of walking (e.g. diễu hành (March), đi vội (hurry))

Manner of jumping (e.g. nảy lên (bounce), bật lên (spring))

\section{b. Narashimban's classification}

Mode: motion brought about by specific types of movements of the Figural entity. (e.g. đi nước kiệu (amble)), đi tập tễnh (hobble), chạy (run)

Attitude/ display: expresses specific kinds of movements but additionally implies an attitude or intention on the part of the Figural entity.

(e.g. lén đi/ trốn đi (sneak), dẫm/ giậm (swagger)), đi chậm chũng (toddler)

Velocity: speed as the main component, (e.g. lao vào (rush).

Contact: implies friction between the Figure and the Ground.

(e.g. truợt (glide), truòn/ bò (slither))

Medium: encodes properties of the medium through which the Figure move.

(e.g. bay (fly), boi (swim)) 
Vehicle: (e.g. lái xe (drive), đi thuyền buồm (sail), đi ca nô (canoe)

Course: (e.g. bay luợn/ bay liệng (hover), đi ngao du (ramble), đi lạc (stray))

Therefore, this research will draw on these two approaches to decompose the manner motion in Vietnamese in terms of semantic properties as well as syntactic properties.

\section{Research Methodology}

This section focuses on shedding light on the methods to analyze the features of Talmy's theory of conflation and the procedure of collecting the data. Also, a research question was raised to provide the researchers with focus for implementing this study.

\subsection{Research Question}

The study focuses on identifying the semantic and spatial elements such as Figure, Ground, Vehicle, Manner and Purpose conflated into the manner motion verbs. Thus, it is set up to answer the question: What components of semantics and space do linguistic surface forms encode and by what means?

\subsection{Methodology}

This section will discuss the prominent method adapted to analyze the data, which is the descriptive. This method helps elucidate the principles concerned with the description of how motion is conceptualized, and other properties of lexicalization patterns. The goal of the descriptive method enables the researcher to test hypotheses and answer the questions (Mitchell \& Jolley, 2010: 205). Descriptive researchers generally embark on answering "what" question about a single variable, such as what are semantic and spatial elements conflated into the manner motion verbs, then expanding to "How", "Where", "Who" questions, etc., such as how are these elements lexicalized?

In order to answer the question of how the semantic and spatial elements are conflated into the manner motion verbs, the interpretation of characteristics of cognitive linguistics is really desirable. Based on the properties of cognitive linguistics, motion may be conceptualized in three prominent ways.

To begin with, motion covers a wide range of situations involving changes of spatial configurations. Therefore, it is said to be conceptualized as a change of location of an object with respect to other objects successively from one point to another along a spatial extent over the time period through spatial cognition. Talmy $(1985,2000)$ calls this type of motion translation motion as in (1a), and another is self-contained motion which exhibits dynamic spatial properties in the entity itself without displacement of its whole body (1b).

(1) a. Chị ấy đi tù̀ phòng sau đến ban công.

She went to the balcony from the back room.

b. Tù xa xa, nhũng hàng cây đang đung đưa trong bóng tối

The trees were swaying darkly in the distance.

(NCT in grade 12)

With its change of locations in space, a translational motion event has a natural starting point to begin the motion, a clear path consisting of an intermediate sequence of locations to follow in the motion, an intended endpoint to stop location, and an inherent pointing from the starting point to the extended endpoint.

Second, the ways in which we perceive translational motion occupy a crucial role in our conceptualization of the world. In other words, the ways in which motion is conceptualized are like the ways in which humans interact with the external world through the process of embodiment and image schemas. For example, "phòng" (the room) in (2) is embodied as a container in a real world, and the action of "chạy ra ngoài" (ran out of the room), is conceptualized as a movement from the inside of the container to the outside of the house.

\section{(2) Bọn trẻ chạy ra khỏi phòng}

Children ran out of the room.

\section{(PT in grade 6)}

Motion is conceptualized through the cognitive process of foregrounding certain portions of an event-frame called windowing of attention and gapping. Tamly (2000a: 258-309) means that windowing of attention is a process of placing a portion of a coherent reference situation into the foreground of attention by the explicit mention of that portion, while gapping is a process of placing the remainder of that situation into the background of attention by omitting mention of it. 
In a motion event, the Path is an essential component because it may draw attention to its initial and final points. It can be described by an object physically in motion during the period of time, thus it has beginning and end. Talmy distinguishes three positions along the path that can be foregrounded: initial, medial, and final windowing as in Figure 2. It is considered as Path-windowing.

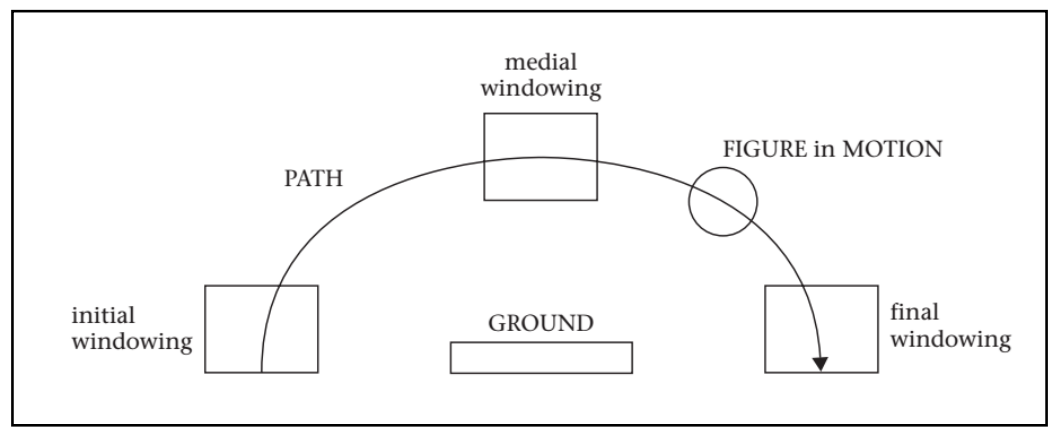

Figure 2. Schematic representation of positional types of windowing

\subsection{Participants}

The participants chosen in this study are fifty $12^{\text {th }}$-graders and fifty $6^{\text {th }}$-graders at Phu Rieng secondary school, Binh Phuoc province, Vietnam. The aim of selecting the participants of different ages is to discover their competence in expressing motion through their ways of conceptualizing motion.

\subsection{Data Collection Procedures}

The story "Frog where are you" by Mayer is the wordless story. It is involved in activities of the boy and three animals (a dog, a hawk and a frog). A great number of activities in this story are related to motion. After the story was delivered to the participants, they were asked to retell the story by writing down a 500-word story based on the activities of the boy, the dog and the frog.

The students' writings were collected and read through one by one to select sentences with manner motion verbs (e.g., chạy, đi bộ, or náy lên). Then they were classified into 11 types of lexicalization patterns based on semantic elements conflated into manner motion verbs. Based on the theory of conflation, each of lexicalization patterns of conflation was decomposed from properties of semantic components conflated into the motion verbs. These properties were elucidated on three factors such as (1) the number of semantic components conflated into verbs; (2) types of semantic components conflated into verbs; and (3) the number of motion verbs corresponding to this kind of pattern.

\section{Findings and Discussion}

This section focuses on analyzing the data. The analysis is conducted on two linguistic features, which are syntactic and semantic features. With respect to syntax, this research is constrained in the scope of argument structures, in which several arguments being able to combine with manner verbs will be illuminated. For the case of semantic features, the current research is associated with the analysis of the semantic roles of arguments. That is, different semantic roles of argument resulting in a wide range of motion events will be radically decomposed. In addition, this research also takes in-depth insights into how semantic components (e.g., manner, ground, figure, vehicle, etc.) are conflated into the manner verbs.

\subsection{Argument Structures}

An argument structure may be interpreted as participants around the main verbs termed as VALENCY in order to constitute a grammar construction (Goldberg 1995, Mani \& Pustejovsky 2012, Croft 2012, Hilpert 2014, Perek 2015, Le Kinh Thang 2016). According to Mehler, et al (2015:176), verb valency determines, besides other things, the number of words obligatory dependent on the verb in a sentence and it plays a decisive role in the sentence structure. Moreover, Perek (2015: 15) posits that the meaning of a verb is inherently relational: it involves one or more entities (or arguments) that are necessary for the situation it describes to be conceived of.

Accordingly, the study of argument structures of motion events revolves investigation into a number of arguments combining with the manner verbs. Table 1 summarizes arguments around the main verb in motion events, in which they are grouped into four categories as follows: (1) a number of arguments; (2) types of arguments; (3) the manner verbs; and distributions of each type. 
Table 1. The argument structures of the verbs of manner motion

\begin{tabular}{lllllll}
\hline No & $\begin{array}{l}\text { Number of } \\
\text { arguments }\end{array}$ & Types of arguments & \multicolumn{2}{c}{$\begin{array}{l}\mathbf{6}^{\text {th }} \text { grade } \\
\text { students }\end{array}$} & \multicolumn{2}{c}{$\begin{array}{l}\mathbf{1 2}^{\text {th }} \text { grade } \\
\text { students }\end{array}$} \\
\cline { 4 - 7 } & & & Verbs & Per & Verbs & Per \\
$\%$
\end{tabular}

a/ V[ Figure]

This expression shows that there is only one argument appearing with the manner verbs. According to the result of the data, there are 18 verbs of the Vietnamese manner verbs (36\%) and 17 verbs of Vietnamese manner verbs (34\%), which the students in grade 6 and grade 12 use, respectively, therefore, it is possible to say that this pattern is not commonly used in Vietnamese. The argument in this pattern functions as a Figure which is the agent of motion, and can be an agentive as in (3a) or non-agentive subject as in (3b). More particularly, all the manner verbs in this expression are intransitive verbs.

(3) $\mathrm{a}$. Những con thằn lằn và rắn đang bò.

(All sorts of lizards and snakes were crawling.)

b. Những trang sách của nhật ký bắt đầu thổi đi.

(The pages of the diary began to blow.)

(TTB in grade 12)

Furthermore, when using this pattern to talk about motion, speakers mostly pay much attention to the Figures which seem to be more prominent than other elements of motion (e.g., bò and thổi). It is possible that the spatial correlation of the Figure with surrounding things is not necessary. As a result, conceptualizing the Path and Ground are not mentioned since it may be tacit. Finally, when the Figure is nonagentive, in fact, it is partly metaphorized because in this case, the Figure does not really give rise to that style of motion as in (4). The manner verb thổ mostly goes with the agentive Figure.

(4) Làn gió lạnh đang thổi mạnh.

(A cold breeze was blowing hard.)

(TML in grade 6)

\section{b/V [ Figure Satellite]}

There are 32 English verbs of manner making up $64 \%$ and 23 verbs occupying $46 \%$ which are used by the students in grade 6 and grade 12 respectively. This pattern encompasses two arguments which are the Figure and the Satellite, which denote the agent, motion and direction as in (5).

(5) Đối thủ đang nhảy lên nhảy xuống.

(NHP in grade 6)

(The opponent is bouncing up and down.)

In this example, the Figure đối thu is the subject of motion, the verb nhảy expresses motion and the motional style of the Figure, which denotes that the Figure immediately moves up or away from a surface after hitting it, and so the Figure is normally made of rubber, has springs etc. The last argument in this expression is the satellite lên (up) and xuống (down). This argument is generally an adverb in English denoting the motional direction of the Figure, which is the Figure's movement from a low position up to a higher position and vice versa. It could be that this expression mainly depicts the prominence of the motion manner and the Figure's direction, and the role of the destination which the Figure may reach is not necessary. 


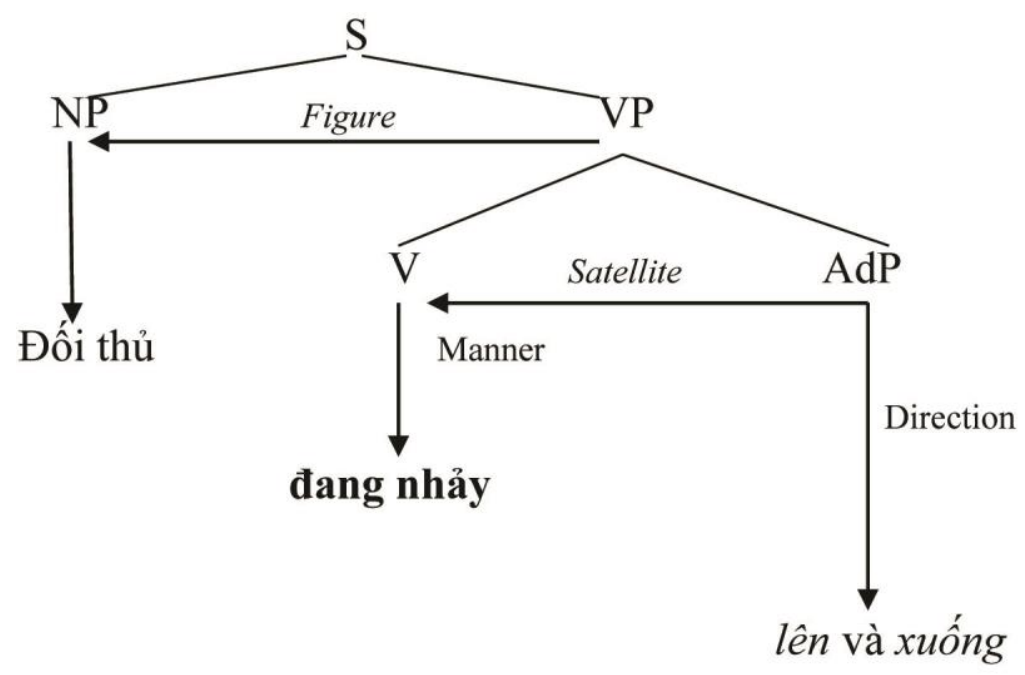

\section{c/ [Figure Figure]}

The manner verbs in this pattern may combine with two arguments, which are the two Figures. These Figures are simultaneously moving toward a certain destination and they could be both agentive and nonagentive subjects. More precisely, the second Figure functions as a direct object; and therefore, the manner verbs must be transitive verbs. This pattern is the least common pattern in Vietnamese. There is only one Vietnamese verb used by the groups of participants making up 2\%, which is chay vuoot qua (outrun). The verb chay vuoot qua denotes that one Figure is simultaneously moving with another Figure, however, the first Figure is moving faster and past the second one as in (6).

(6) Tôi có thể chạy vưọt qua anh ấy, nhưng tôi biết anh ấy rất thông minh.

(I was able to outrun him, but I knew he was clever.) (NCS in grade 12)

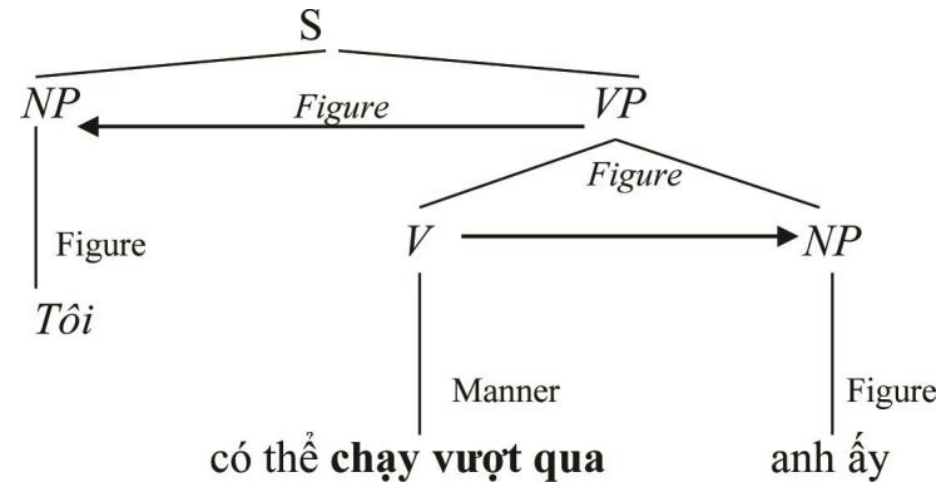

\section{$d / V$ [Figure Place]}

This pattern consists of two arguments, which are the Figure and the Place. The first element denotes motion and the change of position and the second element denotes the place where the motion takes place. There are 42 verbs of Vietnamese manner verbs $(82 \%)$ for the participants of the $6^{\text {th }}$ grade and 36 verbs $(72 \%)$ for the participants of the $12^{\text {th }}$ grade. When expressing this pattern in Vietnamese, the students of both groups seem to focus on the topological conceptualization which denotes the relationship between the Figure and the surrounding things. This relationship is expressed through the distinct semantic features of the relator adpositions which are ở trong (in), ở tại (at), ơ dưói (under), ở trên (on), ở phía sau (behind), ở phía trên (above, over), etc.

(7) Quân lính Anh đi diễu hành trong thao trường.

(HTB in grade 12)

The British troop marched in the parade. 


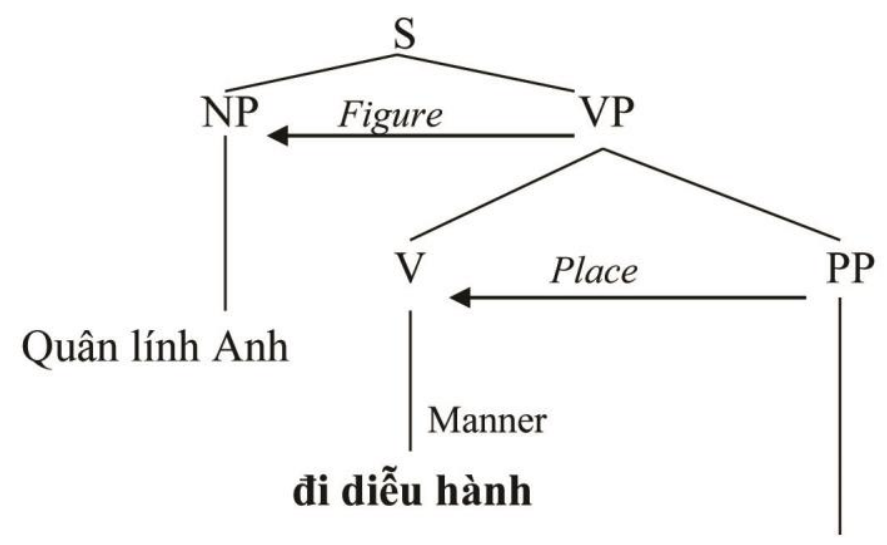

trong thao truòng

\section{e/ V [ Figure Path Ground]}

This pattern consists of three arguments which are the Figure, Path, and Ground. This is the most common expression denoting manner motion in English. There are 39 manner verbs (78\%) used by the participants of the $6^{\text {th }}$ graders and 42 verbs $(84 \%)$ used by the participants of the $12^{\text {th }}$ graders. The Figure in this expression denotes the moving thing like ho (they) in (8); the Path qua (through) denotes the motional direction of the Figure, and the Ground thành phố (the little town) denotes the destination which the Figure is moving towards.

(8) Họ đi bộ qua thành phố tới nhà ga.

(They walked through the little town to the station.)

(LTN in grade 6)

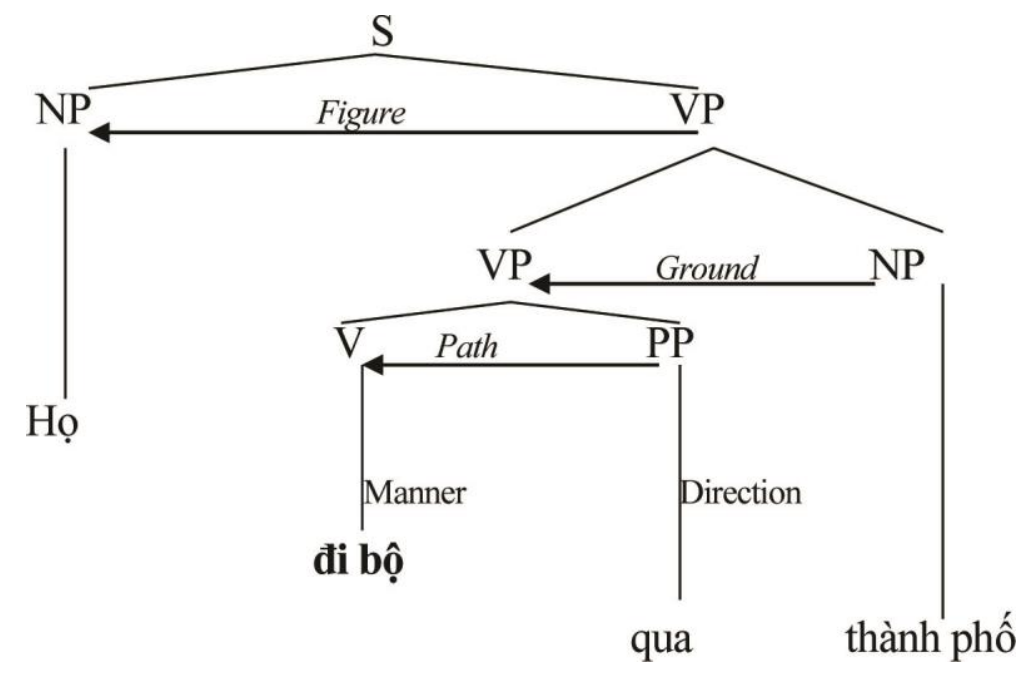

More specifically, the Figure in this expression could be both agentive and nonagentive subjects. However, some verbs only can combine with the agentive subjects such as lái xe (drive), chạy bộ (jog), đi xe đạp (cycle), búng (flip), and gật đầu (nod) etc., and other manner verbs can appear with the nonagentive verbs, which are bồng bềnh (float), nảy (bounce), and đung đưa (swing), etc.,

Nonetheless, there is a limited number of manner verbs which can combine with both the agentive and nonagentive subjects, which are bay (fly), lăn (roll), truọt (slid) and lao vào (rush), etc., Take the verb bay as an example for detailed investigation, the verb bay can appear with the agentive subject as in (9a) and the nonagentive subject as in (9b).

(9) a. Cô ấy sẽ bay về nước ngày mai.

(She's flying back to the States tomorrow.)

b. Tóc của cô ây đang bay trong gió.

(LTB in grade 12)

(Her long hair was flying in the wind.) 
In the case of the agentive subject cô ây (she), the manner verb bay is an active verb in essence because the Figure does not really create motion, but the Figure can move thanks to another Figure which is associated with motion and it is implied.

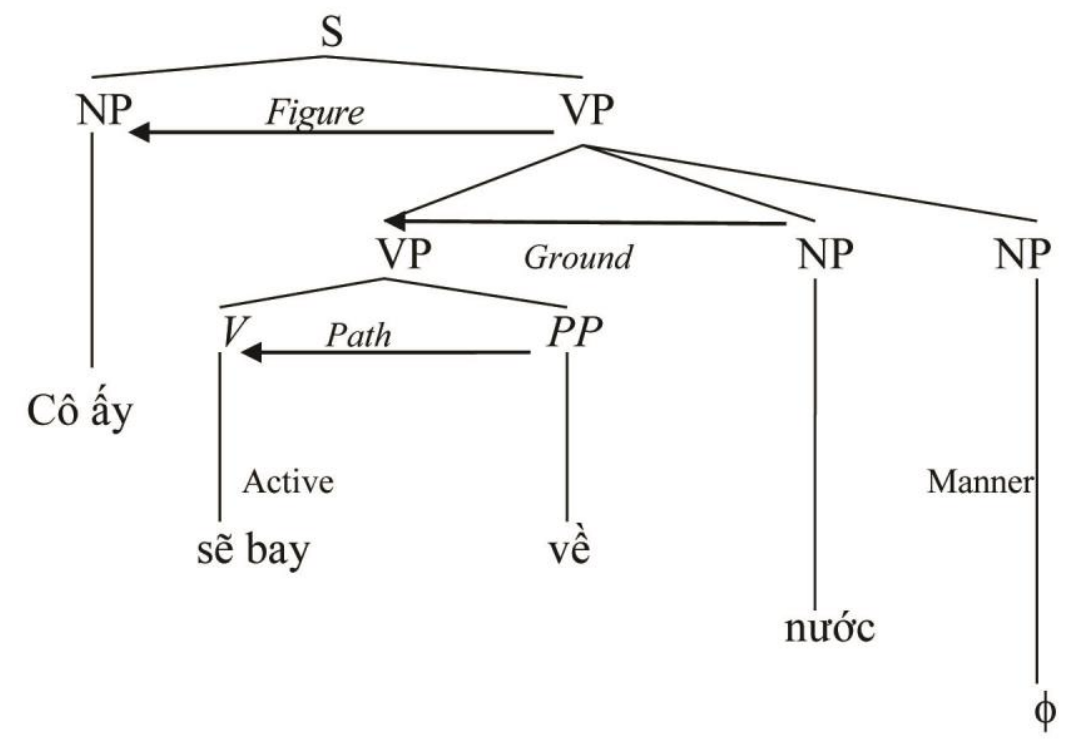

In another case of (9b), the verb bay is a motion manner verb is a translational verb because the Figure is really associated with motion.

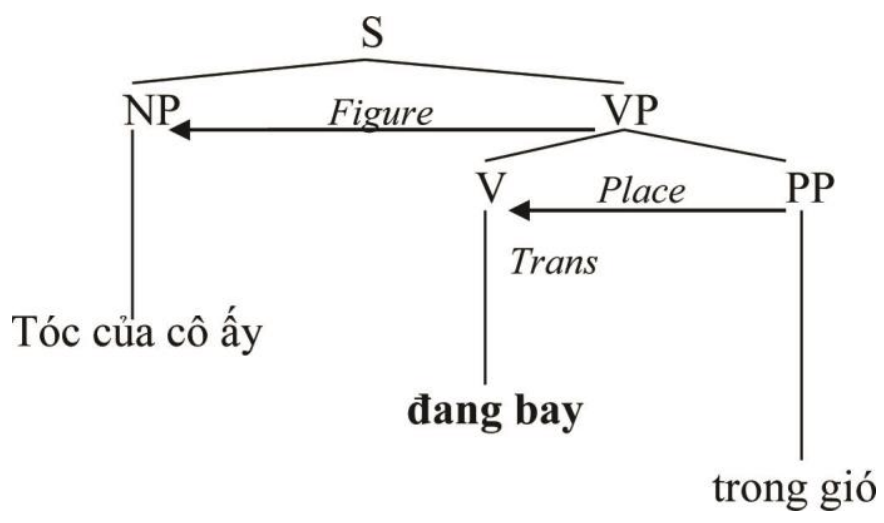

\section{f/V[Figure Satellite Place]}

There are three arguments in this pattern including the Figure, Satellite and Place as in (10). The Figure anh ây (he) denotes the moving object, the Satellite lai (back) denotes the motional direction of the Figure and the last element denotes the place where the motion is taking place. In this expression, the information associated with the manner of motion, the direction and the position are clarified through the lexical semantics of linguistic elements. The Ground which the Figure is moving towards is not mentioned in this expression because the prominent information related to motion is the manner of, direct and place. To be more particular, the speaker's topological conceptualization partly limits the space and position of motion. There are 19 participants of the $6^{\text {th }}$ graders (38\%) using this pattern to describe motion, and 22 participants in grade $12(44 \%)$ using these patterns. Because this pattern is also common in Vietnamese, the number of the participants in the two groups is similar.

(10) Anh ta lê lại trên giường

(He crawled back onto the bed.) 


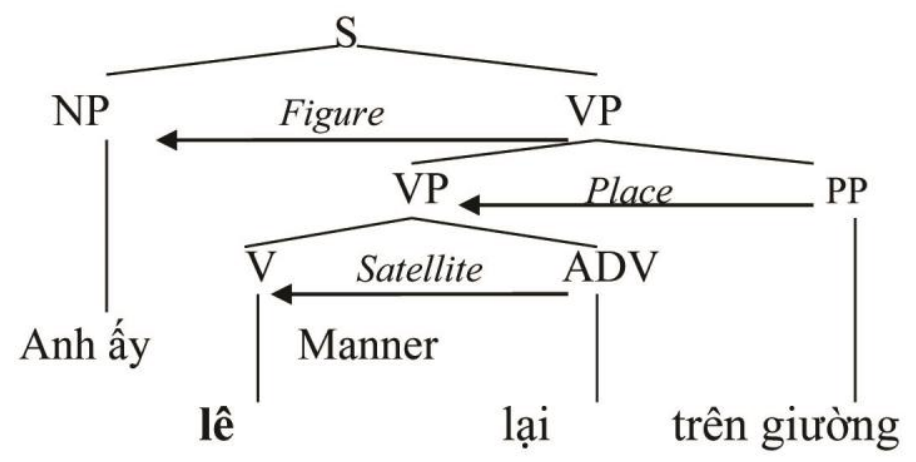

\subsection{Events Structures of LEsMM}

This section is associated with an investigation into the semantic features of lexical expressions of manner motion (LEsMM) in Vietnamese, which is an answer to the question what are semantic features of lexical expressions of manner motion? The types of situations and events of the manner verbs in LEsMM act as a central focus. To be more special, the semantic features of LEsMM are mainly decomposed on the basis of the two lexical aspects of the manner verbs, which are (1) types of motion and (2) types of events.

\section{a/ Types of motion}

The types of motion used by the two groups of participants are summarized in Table 2 below, which are based on Talmy's division including translational motion and self-contained motion. According to Talmy's (2000b), translational motion means that the Figure changes its position from one point to another in space. Next, in self-contained motion, the Figure keeps its same location, and it generally consists of oscillation, rotation, and dilation.

Table 2. Types of manner motion

\begin{tabular}{|c|c|c|c|c|c|c|}
\hline $\mathbf{N}_{\mathrm{o}}$ & Types of man & motion & $\begin{array}{c}\text { Participants in } \\
\text { grade } 6\end{array}$ & $\begin{array}{c}\text { Percentage } \\
\%\end{array}$ & $\begin{array}{c}\text { Participants in grade } \\
12\end{array}$ & $\begin{array}{c}\text { Percentage } \\
\%\end{array}$ \\
\hline \multirow[t]{2}{*}{1} & Translation & tion & 124 & 248 & 179 & 358 \\
\hline & & Oscillation & 3 & 6 & 6 & 12 \\
\hline \multirow[t]{2}{*}{2} & \multirow{2}{*}{$\begin{array}{l}\text { Self-contained } \\
\text { motion }\end{array}$} & Rotation & 28 & 56 & 37 & 74 \\
\hline & & Dilation & 15 & 30 & 26 & 52 \\
\hline
\end{tabular}

\section{Translational motion}

This type of motion is the most common in Vietnanese because the greatest number of students in both grades using this type of motion. It is the semantic features of manner verbs which reveal the essence of the motion. Accordingly, translational motion is the Figure's change in terms of position in space as in (11). The change of position and manner of motion are denoted by manner verbs like nhảy lên (bound), and the direction of motion is expressed by another surface element such as prepositions and adverbs like thẳng "straight"

(11) Thanh nhảy thẳng lên Hùng và bắt đầu liếm tai anh ấy.

(Thanh bounded straight at Hùng and started licking his ears.)

(TTT in grade 12)

Translational motion may appear in a wide range of motional styles and directions. It can be motion with different manners, which are vehicles, etc., đi xe buýt (bus), đi thuyển (boat), đi ca nô (canoe), đi xe đò (coach), đi phà (ferry), or đi tắc xi (taxi) the Figure's styles, etc., cúi (bow), run rẩy (dodder), vẫy (frisk), or nhảy lò cò (hop) or with different directions such as lại (back), lên (up),vào (into), xuống (down), etc.,

\section{Self-contained motion}

This type of motion is clarified by Talmy (2000b), in which he explained that self-contained motion refers to the Figure's motion that is limited in the scope of one's body or its entirely and whose translational position does not change in terms of the reference relation between the Figure and the environment. Self-contained motion includes rotation such as lăn (roll) and xoay quanh revolve, oscillation such as đu đura (sway), lúc lắc (vibrate) and rung (tremble), and dilation such as dậy (arise, rise) and giăng ra (stretch). 
(a)

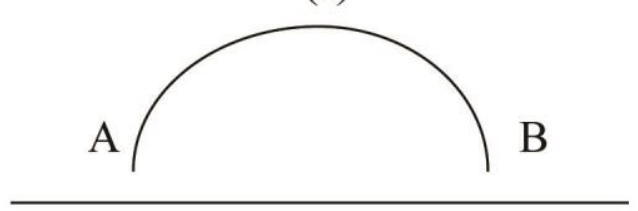

(b)

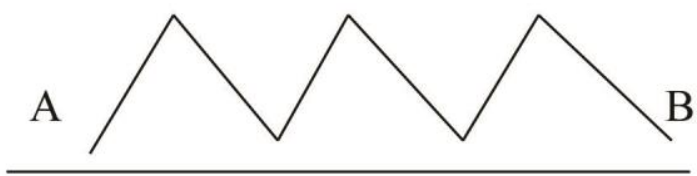

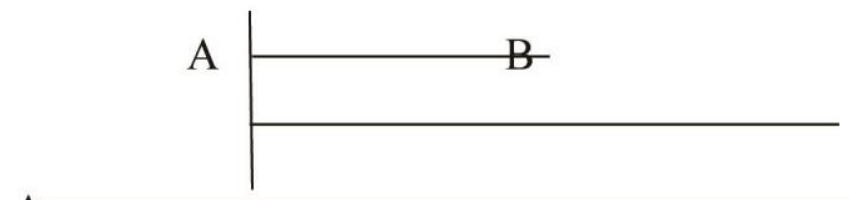

$\mathrm{A}^{-}$

B

(c)

Figure 3. Types of Self-contained motion

First, rotational motion is a type of translational motion in which an object moves from one point to another in a curved path as in Figure 3a. This is the most common self-contained motion in Vietnamese. There are 28 participants in grade $6(56 \%)$ and 37 participants in grade $12(74 \%)$ using rotational motion verbs of the Vietnamese self-contained motion verbs. Next, an oscillatory motion is that motion which moves from one point to another in equal intervals of time; the interval of time is called the time period of periodic motion as in Figure 3b. There are 3 participants in grade $6(6 \%)$ and 6 participants in grade 12 who use verbs of self-contained motion verbs in Vietnamese. The last type of dilation is motion in which the Figure moves from one point to another by exaggerating its limitation as in Figure 3c. This is the least common motion among three types. There are 15 participants in grade $6(30 \%)$ and 26 participants in grade $12(52 \%)$ who use verbs of Vietnamese self-contained motion verbs.

\section{b/ Types of events}

Table 3 summarizes the types of events in Vietnamese which the verbs of manner motion denote. This table is grouped into four categories as follows: (1) types of events such as States, Activities, Achievement, and Accomplishment; (2) features of each event including Atelic, Telic or State; (3) a sum of verbs denoting those events; and (4) the frequency of verbs denoting each type of events.

Table 3. Types of events denoted by manner verbs

\begin{tabular}{|c|c|c|c|c|c|c|}
\hline $\mathbf{N}_{0}$ & Types of event & Features of event & $\begin{array}{l}\text { Participants in } \\
\text { grade } 6\end{array}$ & Per & $\begin{array}{l}\text { Participants } \\
\text { in grade } 12\end{array}$ & Per \\
\hline \multirow[t]{2}{*}{1} & States & Atelic & 0 & 0 & 0 & 0 \\
\hline & & + Stages & 0 & 0 & 0 & 0 \\
\hline 2 & Activities & $\begin{array}{l}\text { Atelic } \\
\text { - Stages }\end{array}$ & 263 & 526 & 282 & 564 \\
\hline 3 & Achievements & $\begin{array}{l}\text { Telic } \\
\text { - Stages }\end{array}$ & 47 & 94 & 69 & 138 \\
\hline 4 & Accomplishment & $\begin{array}{l}\text { Telic } \\
+ \text { Stages }\end{array}$ & 6 & 12 & 13 & 26 \\
\hline
\end{tabular}

\section{Event of States}

Due to the semantic properties of this event which denotes unchanging situations such as emotional, cognitive condition, therefore, this event does not prevail in Vietnamese.

\section{Event of Activities}

This event denotes dynamic situation which goes on in time. The atelic feature of this event depicts that motion is not necessary to have an endpoint. As a result, these verbs denoting the event of activities are always intransitive verbs or goal such as chay bộ (jog), boi (swim), đi bọ (walk) and chay (run). Accordingly, all manner verbs in English can express this feature of the event of activities. The second feature of this event is - Stage which means that the event is denoted by the verbs 
involving the change in terms of position or situation as well like the example below. All manner verbs found in the data can express this feature of an event.

(12) Giáo sư Tân đang chạy về hướng họ.

Professor Tân was running toward them.

(DMC in grade 12)

\section{Event of Achievements}

The event of achievements denotes dynamic situations that are conceived of as occurring instantaneously. The manner verbs denoting this event often consists of two categories of semantic features, which are Telic and + Stages. For the telic features, it indicates that this event has an endpoint or goal, the feature of - Stages means that this event may change its situation. There are 47 verbs of Vietnamese manner verbs of translational motion, making up 94\%, used by the $6^{\text {th }}$ graders and 69 (138) verbs used by the $12^{\text {th }}$ graders.

\section{Event of Accomplishments}

The event of accomplishments denotes a dynamic situation with a terminal point which is logically necessary for them to be what they are. This event consists of two semantic features, which are Telic and + Stages. For the Telic feature, the event denotes that a situation of motion has an endpoint, and in the case of + Stages, the event frequently expresses any change. The reason why this event denotes a stable situation is that the time between starting point and endpoint is too short that speakers cannot recognize or conceptualize the change as well (e.g., nhỏ giọt (dribble),búng ( flick), nảy (flip) and lao (rush). In order to meet these aspects, the manner verbs denoting this type of event must be the predicate of transitive verbs. This type of event is uncommon in Vietnamese; there are only 6 verbs of Vietnamese manner verbs, making up $12 \%$ used by the $6^{\text {th }}$ graders and 13 verbs $(26 \%)$ used the $12^{\text {th }}$ graders.

\subsection{Lexicalization Patterns of Semantic Components}

This section provides the answer to the second research question: What components of semantics and space do linguistic surface elements encode and by what means? In this section, the different types of patterns found in the data will be outlined and radically described. To be more special, the section focuses on the exploration into the conflation of semantic elements in Vietnamese. The semantic components conflated into motion verbs are divided into two types: internal elements and external elements. The first type contained in the inside motion events is based on the semantic elements determined by Talmy (1985) including Manner, Figure and Ground. The later elements are considered to be the outside ones of the motion events, namely Co-motion, Concurrent Result, Vehicle, and Concurrent Purpose.

The lexicalization patterns are fully based on the semantic properties of the manner motion verbs because they are decisive factors to allow which elements are encoded and what information is expressed in them.

The verb conflations are categorized by considering (a) the number of semantic components lexicalized in the manner verbs, and (b) the semantic information they encode. With respect to the number of semantic elements encoded in the verbs, the lexicalization pattern fall mainly into 3 types as follows: (i) the lexicalization pattern with the conflation of one element (type a), (ii) the lexicalization pattern with the conflation of two elements (type b, c, d); and (iii) the lexicalization pattern with the conflation of three elements (type e, f, g, h, i, j). In terms of types of elements, the lexicalization pattern fall into two classes: (i) the lexicalization pattern with the conflation of internal elements (type a, b, $\mathrm{c}, \mathrm{d}$, ) and (ii) the lexicalization pattern with the conflation of external elements (type e, $\mathrm{f}, \mathrm{g}, \mathrm{h}, \mathrm{i}, \mathrm{j}$ ).

Table 4 summarizes the general conflation of semantic elements into lexicalization pattern in the Vietnamese language, which is found in the data. These conflation patterns are grouped with respect to (i) the number of semantic elements conflated in the manner motion verbs (e.g., one, two or three); (ii) kinds of semantic elements (e.g., internal or external); (iii) a number of manner motion combining with semantic components; (iv) a number of students using lexicalization patterns. 
Table 4. Vietnamese students using different lexicalization patterns of motion

\begin{tabular}{|c|c|c|c|c|c|c|c|}
\hline \multirow{2}{*}{\multicolumn{2}{|c|}{\begin{tabular}{|l|}
$\begin{array}{l}\text { Number } \\
\text { elements }\end{array}$ \\
Types of \\
elements
\end{tabular}}} & \multirow[t]{2}{*}{ Lexicalization patterns } & \multirow[t]{2}{*}{ Verbs } & \multicolumn{2}{|c|}{$\begin{array}{l}\text { Participants in } \\
\text { grade } 6\end{array}$} & \multicolumn{2}{|c|}{$\begin{array}{l}\text { Participants } \\
\text { in grade } 12\end{array}$} \\
\hline & & & & Num & $\begin{array}{l}\text { Per } \\
\%\end{array}$ & Num & $\begin{array}{l}\text { Per } \\
\%\end{array}$ \\
\hline \multirow[t]{3}{*}{1} & internal & Motion & 3 & 12 & 24 & 8 & 16 \\
\hline & Total & & 3 & 12 & 24 & 8 & 16 \\
\hline & & Motion + Manner & 164 & 32 & 64 & 47 & 94 \\
\hline \multirow[t]{7}{*}{2} & internal & Motion + Ground & 10 & 21 & 42 & 29 & 58 \\
\hline & & Motion + Figure & 8 & 11 & 22 & 36 & 72 \\
\hline & & Motion + Concurrent result & 5 & 17 & 24 & 21 & 42 \\
\hline & Total & & 187 & 81 & 162 & 133 & 266 \\
\hline & & Motion + Manner + Ground & 7 & 22 & 44 & 24 & 48 \\
\hline & internal & Motion + Manner + Co-motion & 1 & 9 & 18 & 13 & 26 \\
\hline & & Motion + Figure+ Manner & 4 & 17 & 34 & 22 & 44 \\
\hline \multirow[t]{3}{*}{3} & & Motion + Manner + Concurrent result & 2 & 13 & 26 & 15 & 30 \\
\hline & external & Motion + Manner+ Vehicle & 13 & 48 & 96 & 36 & 72 \\
\hline & & Motion + Manner + Concurrent Purpose & 7 & 19 & 38 & 17 & 34 \\
\hline
\end{tabular}

\section{a. Lexicalization pattern: Motion}

This lexicalization pattern encoding only a semantic internal component is found in the data. This pattern contains three manner motion verbs, which are (e.g., biến (go away), dao động (fluctuate) and di chuyến (move)). Biến and di chuyển refer to a change of posture (self-contained motion) and a change of location (transitional motion). Di chuyến is conceptualized as the prototypical manner verb with the most typical meaning of motion. Last, the pattern with the verb dao dộng denotes the Motion with regular changes. The number of the participants in grade 6 uses this pattern more than the participants in grade $12\left(24\right.$ the $6^{\text {th }}$ graders making up 24\% and 8 the $12^{\text {th }}$ graders making up 16\%) because these verbs are the most typical ones to express motion.

\section{b. Lexicalization pattern: Motion + Manner}

This type of pattern is the conflation of two internal elements, which are motion and manner. This pattern regularly refers to the mode of motion such as chay, bò, nhảy, etc. It is most frequent motion found in the data in that there are 164 manner verbs which are found in Vietnamese belonging to this lexicalization pattern. 32 the $6^{\text {th }}$ graders $(64 \%)$ and 47 the $12^{\text {th }}$ graders (94\%) use this pattern to describe movements of those animals. For this pattern, the number of students in grade 12 uses this pattern more than students in grade 6 because some descriptions of motion require highly lexical expressions such as truòn (crawl), đi rón rén (tiptoe), thập thò (waver).

\section{c. Lexicalization pattern: Motion +Ground}

This pattern contains two semantic elements (motion is the internal element and the ground is the external element). Within this pattern, the ground (motion-event component) does not by itself conflate with the motion verbs to express motion, that is, to specify particular ground object plus the fact of Motion, without any indication of Path. The verbs such as cất cánh (move from the ground into the air), ha cánh (landing on the ground from the air), lan truyền (transfer), ra khoi (move away from the shore), and luôn chuyển (circulate), etc belong to this pattern. On the other hand, quay (move, go around a place), xoay (revolve), and xoắn (twist) denote motion around, over, or along an area which remains unspecified, therefore they need overt expression in the utterance. Finally, the verbs bay (move through the air) and bay luogn (hover) encode motion through the air, so bay and bay luơn apply to both animates and inanimates. The Figure would determine the manner ò motion, and the verb was thus not coded as a manner verb.

\section{d. Lexicalization pattern: Motion+ Figure}

This pattern is the combination of two semantic elements. The former is an internal element and other is an external one. Motion verbs in this group are also typical verbs which transparently incorporate the body part [Figure] engaged in motion. This pattern commonly contains some verbs such as cúi (bow), gật đầu (nod) and vẫy tay (wave) and bạnh (enlarge). Last, 
the pattern with the manner verb ngoe nguẩy (wag) only applies with innamate with tails, which denotes motion with happiness.

\section{e. Lexicalization pattern: Motion + Concurrent result}

The pattern with the verbs đâm (plunge into), lao (rush into), tông (collide), va (bump against) and $x \hat{o}$ (jostle) is the conflation of two semantic elements in which motion is an internal element and concurrent result is an external element. This pattern denotes motion whose result is the Figure's collision into the Ground.

\section{f. Lexicalization pattern: Motion + Manner + Ground}

The verbs belonging to this pattern include nhảy dây (move together with a rope), đi cà kheo (move together with stilts), nhảy rào (jump over the fence), nhảy sào (jump with a pole), boi (move in the water), nội suối (move in a stream) and trèo đèo (climb up the hill). Nhảy dây and đi cà kheo denote that the Figure is moving on the ground and with another tool. Second, nhảy sào and nhảy rào denote that the Figure jumps over an obstacle. Boi encodes motion in and on water (the Figure's body is submerged in water). Next, nội suối denotes walking in water with noise (the part of the Figure's body is submerged). Last, trèo đèo encodes motion on the sloping ground (moving from low position to a higher one).

\section{g. Lexicalization pattern: Motion + Figure+ Manner}

This pattern contains manner verbs involving one's foot or feed as Figure which moves in a distinct manner. This pattern is associated with three semantic elements in which Motion and Manner are internal elements and Figure is an external element. The pattern with the manner motion verb such as buóc (step) generally denotes that the Figure is walking as performing these actions, whereas the pattern with the verbs giậm (tread), giấm (trample), and đạp (kick), the Figure do not need to perform an action of walk. Furthermore, while đạp encodes a type of forceful and violent motion when placing somebody's foot on somebody or something, which can cause damage, the pattern with giẫm and giậm denote information with the Figure's angry manner.

\section{h. Lexicalization pattern: Motion + Manner + Vehicle}

Boi xuồng (move by canoe), chèo thuyền (row), đi ca nô (canoe), đi phà (move by ferry), đi xe bus (move by bus), đi xe đạp (bike), đi xe máy (motorbike), đi taxi (move by taxi), đi xe truợt tuyết (move by sled), đi xe ngựa (move by cart), đi xe đò (move by coach) and lái xe (drive).

This pattern denotes the ways of the Figure's movement in which the Figure is not directly associated with motion. The Motion arises from a kind of vehicles (e.g., ca nô, thuyền, phà, xuồng, xe đạp, xe máy, taxi, xe đò, xe ngụa and xe truợt tuyết). Therefore, this pattern with these manner motion verbs is generally named after those transportation means.

\section{i. Lexicalization pattern: Motion + Manner + Co-Motion}

This pattern contains three semantic components, which are Motion, Manner and another motion. All semantic elements in this pattern are internal. This pattern is the combination ò the Figure and the Manner. The pattern with the verb chay truóc the Figure runs farther and faster than another Figure moving at the same time.

\section{j. Lexicalization pattern: Motion + Manner + Concurrent Purpose}

Chạy trốn (escape), chạy thoát (run away), chạy đua (race), chạy mất (run away in abrupt manner), đi học (go to school), di làm (go to work), đi chọ (go to the market).

This pattern is the conflation of three semantic components in which motion and manner elements are internal and the rest (concurrent purpose) is external. Đi học and di làm verbs denote the motion and the action which is the purpose of that motion. These verbs are the combination of two verbs in which the first verb is the manner motion and the later is a dynamic verb. Đi chọ and đi chùa verbs are the combination of the manner motion verb and a place that is the destination of that motion. However, chạy trốn, chạy thoát, chạy đua, and chạy mất encode the motion and another action following that motion to achieve certain purposes.

\section{l. Lexicalization pattern: Motion + Manner+ Concurrent result}

This pattern encodes three semantic components with two internal elements and one external element. The pattern with the verb vuoot denotes that the Figure starts later than another Figure, after that Figure runs faster and overruns the other Figure. Unlike the verb overrun in English, this pattern with the verb ruọt implies the attempt of the Figure, while the pattern with overrun in English only denotes the speed of the Figure.

\section{Conclusion}

This paper concentrated on the investigation into the lexicalization patterns of manner motion in Vietnamese. To be more specific, it revolved the process of rendering human conceptualization into language and vice versa. In other words, it was 
associated with how the semantic elements standing for human conceptualization were mapped onto the surface elements standing for language. Based on the four semantic components identified by Talmy (1985) including Figure, Ground, Manner and Satellite; the researchers have shed light on the semantic and syntactic features of lexicalization patterns of manner motion in Vietnamese. More concretely, the researchers focused on the analysis of how Vietnamese people express manner motion. For the syntactic features, the argument structures concerned with the number of linguistic elements can go with the manner verbs, and the case of semantic features, lexicalization patterns of semantic components are rendered into language.

The data were selected from Vietnamese secondary school students' writing. They were asked to describe the wordless picture Frog where are you by Mayer (2003). The data reveal that lexicalization patterns denoting motion in Vietnamese are diverse. The manner motion can simultaneously denote different semantic components and the satellite also express different semantic elopements. The data analysis also shows a great difference in using the manner verbs to describe motion between the two groups of participants involved in the research.

\section{Reference $s$}

Ferez, P. C. (2008). Motion in English and Spanish: A Perspective from Cognitive Linguistics, Typology and Psycholinguistics. Ph.D. Thesis. University of Murcia.

Ibarretxe- Antunano, I. (2004). What is Cognitive Linguistics? A New Framework for the Study of Basque. In J.I. Hualde \& J. Ortiz de Urbina (2003): A Grammar of Basque. Amsterdam and Philadelphia: John Benjamins, p.36.

Ly Ngoc Toan. (2013). Typology of Motion in Vietnamese in Comparison with English. Scientific Journal of Thu Dau Mot University, 13, p.41.

Mehler, A. et al. (2015). Towards a Theoretical Framework for Analyzing Complex Linguistic Networks. Germany.Springer.

Nguyen Lai. (2001). A Group of Directed Words of Movement in Modern Vietnamese. Hanoi. Social Science Publisher.

Nguyen Thanh Minh. (2015). Classification of Motion Verbs in Vietnamese from Cognitive Linguistics. Linguistic Journal in National Linguistic Conference. p.39.

Özçalışkan, S. (2004). Typological variation in encoding the manner, path, and ground components of a metaphorical motion event. Annual Review of Cognitive Linguistics. p. 213. https://doi.org/10.1075/arcl.2.03ozc

Pourcel, S. S. (2005). Relativism in the Linguistic Representation and Cognitive Conceptualization of Motion Events across Verb-framed and Satellite-framed languages. Ph.D thesis: University of Durham.

Slobin, D. I. (2004). The many ways to search for a frog: Linguistic typology and the expression of motion events. In S. Strömqvist \& L. Verhoeven (Eds.), Relating events in narrative: Typological and contextual perspectives in Translation. Mahwah, NJ: Lawrence Erlbaum Associates.

Slobin, D.I. (2006a). What Makes Manner of Motion Salient? Exploration in Linguistic Typology, Discourse and Cognition. In Maya Hickmann \& Stephane Robert (eds): Space in Language: Linguistic Systems and Cognitive Categories. Amsterdam: John Benjamins, p. 146. https://doi.org/10.1075/tsl.66.05slo

Slobin, D.I. (2006b). Typology and Usage: Exploration of Motion Events across Languages. Paper given at the V International Conference of the Spanish Cognitive Linguistic Association, University of Murcia, Spain, p.231.

Talmy, L. (1974). Semantics and Syntax of Motion. In Syntax and Semantics 4, ed. John Kimball. New York: Academic Press, p. 247.

Talmy, L. (1985). Lexicalization Patterns: Semantic Structure in Lexical Forms”. In T. Shopen (Ed.), Language typology and lexical descriptions: Vol. 3.Grammatical Categories and the Lexicon. Cambridge: Cambridge University Press, p. 194.

Talmy, L. (1991). Path to realization: a typology of event conflation. Berkeley Linguistic Society, p. 241. https://doi.org/10.3765/bls.v17i0.1620

Talmy, L. (2000a). Toward a cognitive semantics: Vol. I: Concept Structuring System. Cambridge, MA: MIT Press.

Talmy, L. (2000b). Toward a cognitive Semantics: Vol. II: Typology and process in concept structuring. Cambridge, MA: MIT Press. 